\title{
PROMOTION OF CLEAN COAL TECHNOLOGIES FOR MEETING ENERGY DEMANDS IN A SUSTAINABLE MANNER
}

\author{
Mrinal K. Ghose* \\ Consultant: Asian Development Bank in Vietnam \\ 113 Regent Estate, Kolkata -700092, India \\ *Corresponding e-mail: ghosemrinal@ hotmail.com
}

\begin{abstract}
The global energy requirement has grown at a phenomenon rate and the demand of coal will continue to remain as the prime energy source in foreseeable future. Economic development and poverty alleviation depend on securing affordable energy sources and coal mining industry offers a bright future for the energy security in the Asia Pacific Region, However, direct use of coal leads to environmental pollution. The emission of $\mathrm{CO}_{2}$, the principal green house gases $(\mathrm{GHG})$, is strongly related to the use of fossil fuel, especially coal, for energy production. A long term projection for the Indian energy sector up to the year 2031-32 show that $\mathrm{CO}_{2}$ emission from India is likely to increase much faster to 3.5 times the present value. Estimated global temperature increase varying from 2 to $3.5^{\circ} \mathrm{C}$ and a sea level rise of $65 \mathrm{~cm}$ by the year 2100. As coal will be reaming as the prime energy source this paper emphasizes the need to develop clean coal technologies where coal can be refined in coal refineries to obtain different fractionated products having different quality grade class (QGC) of fuels. It also highlights the need to develop further clean coal technologies like integrated gasification combined cycle (IGCC) through hydrogen generation for zero emission. The use of ultra clean coal in gas turbines directly will enhance the efficiency of power generation to 52-55\% from the existing efficiency of pulverized coal power generation of 33 - 38\%. This paper discusses the role of Mechanical Engineers for the promotion of Clean Coal Technology (CCT) in fulfilling energy demand in a sustainable manner. Brute force high pressure coal conversion processes will have to be replaced by the convenient and cost effective low atmospheric pressure processes through further research and development work. The methodology as discussed may have formed a guideline to develop clean coal technologies in industrial scale in various countries.
\end{abstract}

Key Words: : Primary energy, oil equivalent, fossil fuels, greenhouse, zero emission, sustainable

\section{INTRODUCTION}

The requirement of primary energy sources is growing exponentially all over the world (Ghose 2002a). The global primary energy requirement has grown from $6700 \mathrm{MtOE}$ (Million tonne oil equivalent) to $10200 \mathrm{MtOE}$ over the last 25 years. There has been a very high positive growth in consumption of all kinds of primary energy sources e.g. oil, natural gas, nuclear energy, hydro electricity and coal (Anon 1988). Coal enjoys the main primary energy source status in Asia Pacific, which comprises the largest population, and an economy that outperforms rest of the world in growth (Ghose 2004). The reserve-to-production (R/P) ratio in respect of major regions of the globe describes the life of different fossil fuels on earth on the basis of current level of production (Barney 1980). The fact remains that oil and gas have limited reserves to last 41 and 67 years respectively at current production level. In contrast, world has a coal reserve to last 190 years at the current production level.

It follows that due to limited oil and gas resources, countries allover the world will have to depend on coal in foreseeable future for their primary energy requirement. Coal is widely available allover the world and is affordable. Its abundance, ease of storage and transportation and wide distribution over the globe determines a competitive international price. World has a proved reserve of 880 trillion tonne ( $\mathrm{Tt})$ of coal including anthracite and bituminous coal. A major part of this reserve (838 trillion tonne) is spreaded over three major regions viz. North America (254.4 Tt). Europe and Eurasia (287.1 Tt) and Asia Pacific (297 Tt) . The abundant reserves of coal spread almost allover the globe provides an energy security. Due to its low prices availability and transport ease, coal has become a popular choice as primary energy source in AsiaPacific region that account for highest coal production and consumption in world. However, direct use of coal leads to environmental pollution. Coal has always been treated as a not so clean fuel but it is still a major fuel of power generation in several countries of the world such as Poland (94.7\%), S. Africa (92.2\%), China (77.5\%), Australia (76.9\%), India (70\%), Czech Rep. (61.8\%), Greece (60.4\%), Denmark (55.1\%), Germany (52.2\%), USA $(52.2 \%)$, Indonesia $(39.7 \%)$. The objective of this paper is to examine the promotion of clean coal technologies to meet the environmental challenges and the role of Mechanical Engineers for the promotion of CCT in fulfilling energy demand in a sustainable manner in the Indian context.

ECONOMIC DEVELOPMENT AND

GREENHOUSE GAS EMISSIONS IN

DEVELOPING COUNTRIES 
The main environmental problems of developing countries stem from poverty and malnutrition. The solution to these problems is more development, not less. This principle was recognized in the Kyoto Protocol, which imposed binding requirements only on industrialized countries, not on developing ones. At the time this agreement was negotiated, many parties feared that emission-reduction requirements would hold back the economies of developing nations, leading to greater poverty and ultimately creating more serious environmental issues.

By the time of COP 17, however, it had become clear that some large developing countries - especially China and India - were progressing rapidly on the path toward industrial development. In 1980, China and India accounted for only 7.6 percent of the world's primary energy consumption. By 2008, their combined share had grown to 21 percent (U.S. Energy Information Administration, 2011b).

Despite the rapid growth of their energy sectors, per capita $\mathrm{CO}_{2}$ emissions remain relatively low in these countries. In 2008, the annual per capita rate was 5.3 metric tons in China and 1.5 metric tons in India, substantially below the United States (17.9 metric tons) (World Bank, 2012a).

Given these discrepancies, it is not surprising that developing countries have argued for "equitable emission" rights. These nations argue that they need to keep energy prices at a reasonable level in order to encourage rapid economic development. Thus, they cannot afford expensive measures aimed at controlling greenhouse gas emissions.

\section{Moving toward sustainability}

Although the arguments put forward by the developing countries have merit, there is a tendency to stretch the assertions too far. Developing countries' share of global $\mathrm{CO}_{2}$ emissions is increasing rapidly. China is already the world's largest emitter of $\mathrm{CO}_{2}$, having surpassed even the United States. India is the third largest emitter, although it still emits only about 20 percent as much $\mathrm{CO}_{2}$ as China (Harvey, 2011).

In both developed and developing countries, it will be crucial to achieve sustainability in both production and consumption of products and services. Conservation of energy and natural resources will become increasingly important. The goal is to optimize the quality of life and meet the needs of the current population without compromising the capacity of future generations to meet their own needs.

As economies grow, demand for the earth's natural resources is accelerating, leading to more rapid depletion. Water stress and the impacts of climate change already are having a direct impact on business operations in many parts of the world. Issues involving energy security and access to raw materials are affecting business competitiveness, as are the rising cost of waste disposal and pollution abatement. A paradigm shift is essential if we are to deliver new products and services with lower environmental impacts across their life cycle.

India is now overtaking Japan as the world's third largest economy (based on purchasing power parity), moving up behind second-place China (Shah, 2011). The question is, what sort of development will the country experience in years to come? The challenge lies in achieving economic growth without serious environmental degradation.

\section{COAL AS THE PRIME ENERGY SOURCE FOR INDIA}

India ranks sixth in the world in terms of energy demand accounting for 3.5 per cent of world commercial energy demand (Ghose 2003a). With a gross domestic product (GDP) growth of 8 percent set for the tenth five-year plan (2002-07), the energy demand has grown at 5.2 percent. Although, this commercial energy consumption has grown rapidly over the last two decades, a large part of India's population does not have access to it (Ghose 2002b). . At $479 \mathrm{~kg}$ of oil equivalent ( $\mathrm{kgOE})$, the per capita energy consumption is also low when compared to some of the other developing countries, like Thailand (1,319 $\mathrm{kgOE})$, Brazil (1,051 $\mathrm{kgOE})$ and China (907 $\mathrm{kgOE}$ ). Primary commercial energy demand grew almost three-fold at an annual rate of 6 per cent between 1981 and 2001, to reach 314.7 million tones of oil equivalent (MtOE). India's incremental energy demand for the next decade is projected to be among the highest in the world, spurred by sustained economic growth, rise in income levels and increased availability of goods and services. India's commercial energy demand is expected to grow even more rapidly than in the past as it goes down the reform path in order to raise standards of living.

The all-India installed capacity of electric power generation under utilities was as on $31^{\text {st }}$ January 2005 consisting of 80,201.45 MW of thermal, 30,135.23 MW of hydro, $2720 \mathrm{MW}$ of nuclear, and 2488.13 of wind power. A capacity addition of 41,110 MW has been, targeted for the tenth plan. The requirement of commercial energy was about $412 \mathrm{MtOE}$ and 554 MtOE respectively in 2007 and 2012 respectively (Table 1). The commercial energy demand is estimated to grow at an average rate of 5.6 per cent and 6.1 per cent respectively during the period 200207 and 2007-12.

In India, an area of about 22400 square $\mathrm{km}$ is estimated to cover coal deposits below the earth's surface out of which 11000 square $\mathrm{km}$ has been regionally explored so far for mining. Out of this, an area of 5500 square $\mathrm{km}$ has been explored in detail for actual mining operations. The geological coal reserves of the country are estimated at 245.7 billion tonnes (Bt) as on January 2004. Out of this, proven reserves are $91.631 \mathrm{Bt}$ while $116.174 \mathrm{Bt}$ are indicated reserves and $37.9 \mathrm{Bt}$ are inferred reserves (Anon 2003-2004). 
Globally, the coal accounts for $26 \%$ of the primary energy consumption, whereas in India, it has a share of $46 \%$. In respect of generation of power, the share of coal on global basis is $36 \%$ and in Indian context it is 65\% (Anon 2003-2004). Growth of Indian economy would lead automatically to growth in energy consumption. The dominant position of coal in energy consumption and electricity generation in Indian context is, thus, likely to continue for decades together because of a very comfortable proven reserves position of coal vis-a-vis the increasingly depleting reserves of oil and natural gas. The World Energy Outlook forecasts that India would face high demand of energy in future and coal alone can meet its needs.

\section{Coal demand and supp1y in India}

The demand for terminal year of the year (2006-07) was at $460.50 \mathrm{Mt}$. This means a growth of about 109 Mt during the plan period as against around $60 \mathrm{Mt}$ achieved during the previous two plan periods. The estimated capacity addition of coal based power generation during the plan period was $18300 \mathrm{MW}$ as against actual capacity addition of about $7000 \mathrm{MW}$ during the plan. The coal demands for the terminal years of eleventh plan (2011-12) and twelfth plan (2016-17) are $668 \mathrm{Mt}$ and $816 \mathrm{Mt}$ respectively. The projected gap between demand and foreseeable domestic production capacities is on a rise (Table 1). It is an irony that in-spite of having a plentiful reserve, India is not able to jack up coal production to meet its current and future demand.

\section{CLEAN COAL TECHNOLOGIES}

Clean coal technologies have been put in four main categories i.e. pre-combustion clean coal technologies, during-combustion clean coal technologies, post-combustion clean coal technologies and advanced clean coal technologies. Pre-combustion clean coal technologies include beneficiation of coal, desulphurization of coal, blending or homogenization of coal. Duringcombustion, clean coal technologies are fluidized bed combustion, staged combustion, low NOx burners, boiler tuning for efficient and optimized combustion, super critical and ultra super critical boilers etc. These may include coal-water mixture combustion. Post-combustion clean coal technologies involve flue gas desulphurization (FGD), flue gas denitrogenation, catalytic reduction of NOx, plasma reduction or selective catalytic reduction of NOx, electrostatic precipitators, bag houses, cyclone and other scrubbers etc. to arrest fly ash. Advanced clean coal technologies are Integrated Gasification Combined Cycle (IGCC) power generation, Pressurized Fluidized Bed Combustion (PFBC), IGCC - Fuel Cell power generation, ultra super critical boilers, etc. However, there is a need to make these clean coal technologies economical and if possible more efficient and free of major engineering problems where these exist. Several clean coal technology projects are being undertaken world wide.

Since coal contains mineral matter (ash) and other impurities, the atomic $\mathrm{H} / \mathrm{C}$ ratio of coal is not high; its calorific value is lower than that of oil and natural gas. Therefore, concerns about the pollution caused by the use of coal fuels is increasing. This includes global warming, land degradation due to mining and fly ash disposal, water pollution due to coal washing (Giri and Sharma 2004). There is also a need to add value to coal and thus there is a need to develop clean coal technologies further. Physical coal beneficiation techniques using oil agglomeration, froth flotation, oleo flotation have to be integrated with chemical cleaning of coals (Sharma and Singh1995). Chemical cleaning of coal using alkaliacid leaching under milder conditions may produce cleaner coal. Some research in this direction has been reported, where coal may be cleaned by using HF$\mathrm{HNO}_{3}$ cleaning (Steel and Partic 2003) and by using alkali-acid leaching (Sharma 2005). The thrust is for producing ultra clean coal, a nearly zero ash coal, which may be used for the Integrated Gasification Combined Cycle and for PFBC power generation without any problems of resorting to hot gas clean up. IGCC power generation through hydrogen generation for zero emission has been reported (Zocket al.2003). Co-combustion of coal with plastics, biomass, oil, water, biogas, organic wastes, natural gas, etc. can be practiced for efficient power generation and for adding value to coal.

\section{Coal refineries}

Since oil is refined to obtain different grades of fuels for use differently and efficiently in petroleum refineries, the coal can also be refined in coal refineries to obtain different quality - grade - class (QGC) of fuels. There is a need to develop further clean coal technologies for the stepwise refining of coal to obtain different QGC products as is practiced for crude oil in petroleum refineries. Organo-refining of coal i.e. stepwise solvent extraction of coal using different solvents such as N-methyl -2- pyrrolidone (NMP), anthracene oil (AO), morpholine (MO), ethylenediamine (EDA), quinoline (QN), liquid paraffin (LP), alkenes, phenols, dimethyl formamide (DMF), phenanthrene, carbazole, etc. can produce different QGC products from coal (Pandey and Sharma 2002). Several combinations of solvents can be used for the stepwise refining of coal and the process has been termed as Organo-refining of coals. This may lead to the production of two or three different QGC products from coal. Some of the premium QGC products such as super clean coal having ultra low ash, can be used for the production of graphite, carbon-nanotubes, composites from coal . In fact, super clean coal or ultra clean coal can be used for more than 30 different uses including coking coal blends, carbon electrodes, reduction, 
nanocomposites, value added chemicals, specialty chemicals conducting polymers, engineering plastics, etc. The residual coal obtained after the stepwise organo-refining of coal may be used for power generation. This coal (RC) may be beneficiated or chemically cleaned to obtain cleaner coal. The washability characteristics of the RC can also improve after the removal of some of the organic matter from the coal by solvent extraction (organorefining).Liquefaction, gasification and carbonization of Residual Coal may also produce different QGC products for use differently and may be even efficiently.

\section{Modification of coal for added value}

In fact, depolymerisation of coal through phenolation may enhance the yield of super clean coal (having ultra low ash) through organo-refining of coal. The uses of coal derived from industrial solvents were made for these studies. In fact, coal can be chemically modified under ambient pressure and convenient conditions by reactions such as depolymerisation by phenolation, co-polymerization, alkylation, reductive alkylation, reduction, alkaline degradation, reductive depolymerisation, etc. Most of these processes involve atmospheric pressure operations, at low temperature as brute force high pressure coal conversion processes have to be replaced by the convenient and cost effective low to ambient pressure processes. Liquefaction of coal under mild atmospheric pressure conditions including solvent refined coal processes also affords different QGC products. The unit processes employed in oil refineries may include besides organo-refining, the processes such as carbonization, hydro carbonization, gasification, liquefaction (hydrogenation), cracking, co-cracking, chemical leaching, bio-refining, etc.

The RC can also be utilized through co-combustion with plastics, biomass, vacuum residue, organic wastes, biogas, etc. to generate power by using efficient ultra super critical boilers. Co-processing of $\mathrm{RC}$ or original (untreated) coal with waste plastics, biomass, petroleum coke, vacuum residue, etc. may also lead to cleaner and efficient utilization of coal (Ahmaruzzaman and Sharma 2005 ) by PFBC, IGCC or power generation techniques. Unit processes such as organo-refining, depolymerisation, reduction, reductive alkylation, carbonization, hydro carbonization, hydro cracking, cracking, catalytic cracking, gasification, etc. may form different reactor units in future coal refineries. The role of depolymerization and organo-refining and carbonization or gasification of RC (Anon 2006a) may be worth studies further for their role in future Integrated Coal Refineries.

Most of the techniques of physical beneficiation of coals are already being commercially exploited. In future techniques such as oil agglomeration, froth flotation, etc. may be integrated with biodepyritisation by using patented processes. The flow schemes of beneficiation of coals may be developed further. The rejects may be fired in fluidized bed combustors (FBC). The success of coal blending or homogenization may be dictated by the developments in the technology of solid-solid mixing such as blending in beds, strata, skewed chevron, windrow, chevron-windrow, chevron, blending in silos, blending on moving belts etc.

The US DOE has recently reported (Anon 2006b) an updated status of the DOE commercial - scale demonstration of clean coal technologies (CCTs). These demonstrations involved billions of dollars not only USDOE funding but even the funding support from the participating commercial organizations on cost sharing basis (i.e. federal government, other public institutions, the technology suppliers and users). These were performed under Clean Coal Technology Demonstration Programme (CCTDP), Power Plant Improvement Initiative (PPII) and Clean Coal Power Initiative (CCPI). The CCT research development and demonstration programmes contribute to achieve the DOE strategic goal, including the President's Coal Research Initiative, Future Gen Initiative, Global Climate Change Initiative, Hydrogen Fuel Initiative and Clear Skies Initiative (CSI). The programme further addresses the requirements of the Clean Air Interstate Rule (CAIR) and the Clean Air Mercury Rule (CAMR).

The CCTDP was focused on reducing $\mathrm{SO}_{2}$ and $\mathrm{NOx}$ emissions and on advanced turbines, gas separation membranes, fuel cells, new gasification processes, carbon sequestration, hydrogen production and other advanced energy system technologies. These include low NOx burners staging combustion, oxygenenhanced combustion, selective catalytic and noncatalytic NOx reduction etc (Anon 2006c). Mercury control technologies use sorbents and oxidizing agents and wet-FGD scrubbers ESP and fabric filter dust collectors were used to control even PM 2.5. Advanced power systems include IGCC - Fuel Cell power generation and circulating fluidized bed combustors ( $\mathrm{CFB}$ ) using low grade coals and waste materials. The new advanced systems being developed are hybrid systems integrating IGCC and CFB technologies and advanced combustion using $\mathrm{O}_{2}$ instead of air or chemical looping to effect the equivalent of combustion. The other endeavor includes upgrading goal by removing ash to obtain clean fuels. The work on conversion of coal to liquid fuels, chemicals or hydrogen is also being undertaken. Under industrial applications, direct coal use for substitution of coal in place of coke for coke making and for oil or natural gas in energy production are being undertaken. The work on the utilization of fly ash in cement and in abandoned coal waste piles is in progress. A large number of projects have been successfully completed.

\section{CONCLUSIONS}


Though conventional fossil fuels, which provide primary energy, have limited resources, coal will maintain its dominance in international energy scenario because of its huge reserves that will last for two centuries. Due to environmental concerns, various other energy options including renewable are being tried globally but they have failed to provide bulk energy at competitive cost. So, there is a need to refine coal and coal refineries will have to be set up to obtain different QGC products fractions from coal. Carbon nanotubes, composites, graphite etc. can be obtained from the super clean coal or ultra clean coal. After organo-refining coal can be further refined by washing or chemically cleaning . The RC may be subjected to co-processing i.e. co-combustion or gasification, co-cracking (co-carbonization) or liquefaction along with biomass, vacuum residue, plastics, organic wastes etc. to obtain further different QGC products fractions for efficient utilization. There may be a need for further research work to develop the process of coal refineries involving multi step coal conversion, refining and utilization. This paper emphasizes role of Mechanical Engineers for the promotion of CCT in fulfilling energy demand in a sustainable manner The methodology as discussed may have formed a guideline to develop clean coal technologies in various countries.

\section{REFERENCES}

[1] Ahmaruzzaman, M. and Sharma, D.K., Nonisothermal kinetic studies on co-processing of vacuum residue, plastics, coal and petrocrops, Journal of Analytical \& Applied Pyrolysis, 73, 263275 (2005)

[2] Anon, (1988) The World Resources 1988-89, New York, Basic Books.

[3] Anon (2003-2004) Ministry of Coal and Mines, Govt. of India.

[4] Anon (2006a)Clean Coal Technology Program Update 2006, Office of Clean Energy Systems, U. S. Department of Energy, FE-22, German Building, 1000 Independence Ave, S.W., Washington DC 20585-1290, USA, September.

[5] Anon (2006b) Clean Coal Technology Programs: Program Update 2006, Sept. 2006, US Department of Energy, FE-20/Germantown Building, 1000 Independent Ave. S.W., Washington, D.C. USA.

[6] Anon (2006c) Clean Coal Today - A Newsletter about Innovative Technologies for Coal Utilization, Office of Fossil Energy, US Dept. of Energy, Issue No. 69, Winter 2006

[7] Barney, G.O.(1980). The Global 2000 Report to the President, 2 vols. Washington, D.C. US Govt.Printing Office.

[8] Das, A. and Sharma D.K.,(2000) Organic desulfurisation of Assam coal and its sulfur - rich lithotypes by sequential solvent extraction to obtain cleaner fuel, Energy Sources, 23,pp 687-697.
[9] Ghose, M.K. (2002a) Environmentally sustainable supplies of energy in Indian context, $J r$. Institution of Public Heath Engineers, 2, pp51-56 [10] Ghose, Mrinal K. (2002b) Potentials of geothermal energy, Jr. of Energy in Southern Africa 13(4)pp 144-148

[11] Ghose, Mrinal K. (2004) Impact of mining on female community --a perspective of female miners in the Indian context, Mineral and Energy, 4 pp1624

[12] Giri, C.C. and Sharma, D.K.,(2004) Washability characteristics of residual coals obtained from solvent extraction - Studies towards developing cleaner coal technologies, Indian Chemical Engineer, 46, pp 90-94.

[13] Harvey, F. (2011, January 31). An atlas of pollution: The world in carbon dioxide emissions. The Guardian. Retrievedfrom http://www. guardian.co.uk/ environment /2011/ jan/ 31/ pollution-carbon-issions.commentpage $=1$ \#comment9372993 [14] Pande S. and Sharma, D.K.,(2002) Ethylenediamine - assisted solvent extraction of coal in N-methyl-2-pyrrolidone. Synergistic effect of ethylenediamine on extraction of coal in N-methyl-2pyrrolidone, Energy and Fuels: 16 (1), 194-204

[15] Shah, R. (2011, September 20). India to topple Japan as world's 3rd-largest economy.The Economic Times. Retrieved from http://articles. economictimes. indiatimes.com/2011-09-20/news/30180201_1_thirdlargest-economy-power-parity-indian-economy.

[16] Sharma,D.K, Studies towards the development of effective techniques for deashing (demineralisation) of coals, Fuel Sc. \& Tech. Intl., 14, 1195-1203 (1996).

[17] Sharma, D.K., (2005)Emerging Cleaner Coal Technologies - Concept of Coal Refineries, Proc. Clearwater Coal Conference, Clearwater,Fl, USA, April .

[18] Sharma,D.K., and Singh,S.K., (1995) An advanced process for the production of clean coal, Energy Sources, 17, pp485-493

[19] Steel, K.M. and Patrick, J.W.,(2003) The Production of Ultra Clean Coal by sequential leaching with $\mathrm{HF}$ followed by $\mathrm{HNO}_{3}$, Fuel, 82 (1517), pp1917-1920 .

[20] U.S. Energy Information Administration (2011b). International energy outlook 2011, world total primary energy consumption by region, reference case, 2006-2035.

[22] Ziock, H.J., Lani, Los Almos, and Harrison, D.P (2003) Zero Emission Coal Power A New Concept,.,Deptt. of Chem. Engg., Lousiana State Univ., USA.

Table 1: Estimated primary energy demand in India (Source: ASEAN-India Business Portal*) 


\begin{tabular}{|c|c|c|c|c|c|}
\hline \multirow[t]{2}{*}{ Primary } & \multirow[t]{2}{*}{ Unit } & \multicolumn{2}{|c|}{$\begin{array}{l}\text { Demand } \\
\text { original units) }\end{array}$} & \multicolumn{2}{|c|}{ Demand (MtOE) } \\
\hline & & 2006-07 & $2011-12$ & 2006-07 & 2011-12 \\
\hline Coal & Mt & 460.50 & 620.00 & 190.00 & 254.93 \\
\hline Lignite & Mt & 57.79 & 81.54 & 15.51 & 22.05 \\
\hline Oil & Mt & 134.50 & 172.47 & 144.58 & 185.40 \\
\hline Natural gas & $\mathrm{BCM}$ & 47.45 & 64.00 & 42.70 & 57.60 \\
\hline $\begin{array}{l}\text { Hydro } \\
\text { power }\end{array}$ & BKwh & 148.08 & 215.66 & 12.73 & 18.54 \\
\hline $\begin{array}{l}\text { Nuclear } \\
\text { power }\end{array}$ & BKwh & 23.15 & 54.74 & 6.04 & 14.16 \\
\hline $\begin{array}{l}\text { Wind power } \\
\text { Total }\end{array}$ & BKwh & 4.00 & 11.62 & 0.35 & 1.00 \\
\hline $\begin{array}{l}\text { commercial } \\
\text { energy }\end{array}$ & & & & 411.91 & 553.68 \\
\hline $\begin{array}{l}\text { Non- } \\
\text { commercial } \\
\text { energy }\end{array}$ & & & & 151.30 & 170.25 \\
\hline $\begin{array}{l}\text { Total } \\
\text { energy } \\
\text { demand }\end{array}$ & & & & 563.21 & 723.93 \\
\hline
\end{tabular}

*The coal demand figures are under review and revision

Table 2: Demand-supply gap for the next plan periods*

$\begin{array}{lccccc}\text { Plan term year } & 06-07 & 11-12 & 16-17 & 21-22 & 24-25 \\ \begin{array}{l}\text { Estimated Demand @ } \\ 8 \% \text { growth }\end{array} & 478 & 668 & 816 & 1063 & 1242 \\ \text { Domestic Supply } & 432 & 617 & 772 & 967 & 1134 \\ \text { Gap(Mt) } & 46 & 51 & 44 & 96 & 108\end{array}$

